\title{
Gender and Age Influences on Human Brain Mu-Opioid Receptor Binding Measured by PET
}

\author{
Jon-Kar Zubieta, M.D., Ph.D., Robert F. Dannals, Ph.D., and J. James Frost, M.D., Ph.D.
}

\begin{abstract}
Objective: Both age and gender are being increasingly recognized as important factors influencing CNS structure and function. However, there are relatively few data on actual neurochemical differences between the sexes in human subjects or on their interaction with age. One of the central neurotransmitter systems for which sex differences have been suggested by animal models and clinical human data is the opioid. In this study the authors examined age- and gender-associated variations in mu-opioid receptor binding with positron emission tomography (PET). Method: Healthy human subjects were studied with PET and the radiotracer $\left[{ }^{11} \mathrm{C}\right]$ carfentanil, a selective mu-opioid agonist. Two separate subject groups were examined: one group of 24 men and 12 women was studied in a retrospective analysis of data, and a second group of 12 men and 18 women was recruited prospectively and studied with a higher-resolution scanner. Results: Mu-opioid receptor binding potential $\left(\mathrm{B}_{\max } / \mathrm{K}_{\mathrm{d}}\right)$ was found to increase with age in neocortical areas and the putamen. Sex differences, with higher mu-opioid binding in women, were observed in a number of cortical and subcortical areas. Gender-by-age interactions were observed in the thalamus and the amygdala; in vivo mu-opioid binding declined in postmenopausal women to levels below those of men. Conclusions: These data imply that both age and gender are important variables to consider in the interpretation of investigations of human function in which the opioid system plays a role. Also, women's reproductive status (reproductive age versus postmenopausal) may influence the function of CNS opioid systems.
\end{abstract}

(Am J Psychiatry 1999; 156:842-848)

\begin{abstract}
Sex and age are two variables increasingly recognized as important for the understanding of human brain function and its behavioral and cognitive manifestations. Age-related changes in measures of cognitive function (1) brain structure (2), and brain neurochemistry (3) have been widely described in the literature. Structural imaging studies with computerized tomography $(\mathrm{CT})$ and magnetic resonance (MR) have shown progressive age-associated increases in ventricular and sulcal cerebrospinal fluid (CSF) and associated declines in cerebral hemispheric and gray matter volumes, involving both cortical and subcortical structures $(4,5)$. In these studies the degree of gray matter atrophic changes appeared to be regionally variable (e.g., more pronounced in the prefrontal cor-
\end{abstract}

Received Oct. 15, 1997; revisions received April 27, July 24, and Nov. 16, 1998; accepted Nov. 30, 1998. From the Department of Radiology, Division of Nuclear Medicine, and the Department of Neurosciences, The Johns Hopkins Medical Institutions. Address reprint requests to Dr. Frost, Department of Radiology, The Johns Hopkins Medical Institutions, Nelson, B1-130, 600 North Wolfe St., Baltimore, MD 21287; jfrost@receptor.rad.jhu.edu (e-mail).

Supported by grant AG-08740 from the National Institute on Aging. tex and basal ganglia), and the atrophy progressed faster in the later decades of life.

Functional imaging with positron emission tomography (PET) and single photon emission computed tomography (SPECT) using regional cerebral blood flow $(\mathrm{rCBF})$ and oxygen and glucose metabolic markers have shown conflicting results, although similar patterns are emerging in the published literature. In adults, measurements of rCBF and rates of cerebral oxygen and glucose metabolism most frequently show neocortical and, in some cases, subcortical reductions with advancing age, which may be more prominent in frontal regions (6-8).

Sex differences in the degree of age-associated brain atrophy have also been described; men have earlier increases in ventricular volume than women, as measured with CT, but the increments in women are somewhat faster once they are observable (9). Using magnetic resonance imaging (MRI), Gur et al. (10) found steeper age-associated increments in sulcal CSF in men than in women. They also found more severe left hemisphere atrophy in men, while these changes were more symmetrical in women. 
More recently, gender differences in resting CBF and cerebral glucose metabolism have been examined. Higher resting cortical and global values in women than men have been noted in some studies $(11,12)$. Regionally, higher metabolic rates have been observed in women in the cerebellum and in the cingulate gyrus, with opposite findings in some neocortical and limbic regions $(13,14)$. These data have been interpreted as reflecting the neurobiological substrates underlying sex differences in cognitive and emotional processing. Subsequently, both age and sex influences on brain neuroanatomy and metabolic function have been reported (15). With advancing age, men have greater declines in cerebral hemisphere volumes and frontal and temporal lobe volumes, while women show greater atrophy in parietal and hippocampal regions.

While volumetric and metabolic measurements may point to the brain regions involved in the cognitive and behavioral differences between the sexes, much less is known about underlying neurochemical pathways. One of the various neurotransmitter systems for which regional age and sex influences have been described is the central opioid system. In postmortem human brains, age-associated increases in mu-receptor density, but not affinity, have been shown in neocortical areas, with reductions in the thalamus $(16,17)$. Data directly addressing sex differences in endogenous opioid function, or its modulation by gonadal steroids, are currently not available for human subjects. However, this receptor site is involved in the hypothalamic regulation of reproductive function and in antinociceptive mechanisms, which appear to be influenced by sex and the presence of gonadal steroids $(18,19)$.

In the present study we examined regional differences in mu-opioid receptor binding measures in the brains of healthy human subjects, with the mu-selective agonist $\left[{ }^{11} \mathrm{C}\right]$ carfentanil and PET. The data described represent two separate analyses and subject groups. First, we retrospectively examined data from prior research protocols. In addition, a second study group was prospectively recruited to control for prior hormonal treatments and phase of the menstrual cycle.

\section{METHOD}

Written informed consent was obtained in all cases. The studies were approved by the Johns Hopkins Joint Committee on Clinical Investigation. All subjects were screened for medical, neurological, and psychiatric disorders and for substance abuse. No control was placed on socioeconomic status or educational level. Before the PET studies were performed, the imaging planes were standardized between subjects by using CT or MR imaging and the glabellar-inion line as reference plane, as previously described (20). After intravenous administration of $19 \mathrm{mCi}$ of $\left[{ }^{11} \mathrm{C}\right]$ carfentanil $(\mathrm{SD}=2)$, the subjects were scanned over 90 minutes. A technician then placed square $8 \times 8$-mm regions of interest in the reconstructed images, as will be described, using the structural MR images as templates and while blind to subject groups. Mean counts per region of interest were averaged for each of the lateralized regions (right, left) and the pons, yielding average regional activity levels.

\section{Retrospective Analysis}

This group included 36 subjects, 24 men and 12 women, ranging in age from 20 to 74 years. They were studied as part of various research protocols between 1989 and 1992. The menstrual cycle timing and use of hormonal treatments among the women in this group were not controlled for. The PET studies were performed on a NeuroECAT scanner (CTI, Knoxville, Tenn.) (reconstructed resolution, full width at half maximum: $13.0 \mathrm{~mm}$ in-plane, $14.5 \mathrm{~mm}$ in the $\mathrm{z}$ axis). Three imaging planes were acquired, with a $32.0-\mathrm{mm}$ separation between slices. The scan data were averaged from 35 to 70 minutes (NeuroECAT scanner). Regional mu-opioid measures were obtained by using the following ratio: (region of interest - occipital cortex) $\div$ occipital cortex. The occipital cortex is an area devoid of mu-opioid receptors and an estimate of nonspecific binding. This ratio of specific to nonspecific binding has been shown to be proportional to the ratio $B_{\max } / K_{d}$ for this receptor site (21). This ratio is referred to in the PET imaging literature as "binding potential," and it is probably the most frequently used receptor-related measure in this context (22). Ten brain areas were examined, in one plane each: prefrontal cortex (five regions of interest in each side), anterior cingulate (one region), temporal cortex (seven regions in each side), occipital cortex (two regions in each side), caudate and putamen (one region in each side), thalamus (one region in each side), amygdala (one region in each side), pons (one region), and cerebellum (four regions in each side).

\section{Prospective Analysis}

We prospectively recruited 30 subjects, 12 men and 18 women, whose ages ranged from 19 to 79 years. All reproductive-age women reported regular menses and were studied during the follicular phase of the menstrual cycle (between days 4 and 10 after the last onset of menses), and neither the pre- nor postmenopausal women had taken hormone treatments (birth control pills or replacement therapy) for at least 6 months before the study. The PET studies were performed by using a higher-resolution GE $4096^{+}$scanner (reconstructed resolution, full width at half maximum: $7.7 \mathrm{~mm}$ in-plane, $8.0 \mathrm{~mm}$ in the $\mathrm{z}$ axis, with a $6.5-\mathrm{mm}$ separation between slices), which acquires 15 slices simultaneously. Regional mu-receptor measurements of radiotracer activity were obtained by using the ratio (region of interest - occipital cortex $\div$ occipital cortex for data averaged from 35 to 82 minutes. As previously shown (21), this ratio was selected as accurately reflecting the binding potential $\left(\mathrm{B}_{\max } / \mathrm{K}_{\mathrm{d}}\right)$ for this receptor site. We also performed a series of computer simulations in which changes in tracer transport were simulated. We wanted to ascertain that reductions in $\mathrm{rCBF}$, with their concomitant reductions in tracer transport (transport $=$ blood flow $\times$ tracer extraction) would not influence receptor binding values. Regions of interest were placed in each side of the prefrontal cortex (five regions of interest per plane, three different planes), anterior cingulate (one region of interest, three planes), parietal cortex (four regions of interest, three planes), temporal cortex (seven regions of interest, two planes), occipital cortex (two regions of interest, two planes), caudate nuclei (one region of interest, three planes), putamen (one region of interest, three planes), thalamus (one region of interest, three planes), and amygdala (one region of interest, three planes). In the pons, no lateralized regions were placed (one region of interest per plane, three planes).

Independence of Receptor Measures From Simulated Changes in Tracer Transport

A series of computer simulations was performed to ascertain that gender- or age-associated changes in $\mathrm{rCBF}$, and therefore in the rate of transport of the ligand $\left(\mathrm{K}_{1}\right)$, would not bias the results to any significant degree. Data from a brain region with a high concentration of mu-opioid receptors (temporal cortex) was obtained from a representative subject (43-year-old man). Constants for the rate of tracer transfer between compartments were then obtained by applying a three-compartment model, with arterial blood used as an input function (23). Changes in tracer transport up to $25 \%$ were simulated, and noise-free tissue data were calculated on the basis of the model equations described by the three-compartment, four-parameter model configuration, as previously reported for other tracers 
(23). These simulated changes are greater than those that would be expected with aging or gender differences in $\mathrm{rCBF}$, as reported by other groups (see introduction). The data were then analyzed by using the following ratio for each region: (region of interest - occipital cortex $\div$ occipital cortex. The errors in the perceived receptor binding measured with this method were $0.7 \%$ for a $25 \%$ reduction in tracer transport (three-compartment model $\mathrm{K}_{1}$ ) and $-3.5 \%$ for a $25 \%$ increase in $\mathrm{K}_{1}$. We then concluded that the use of the ratio method (as opposed to more complex compartment kinetic models that require arterial blood sampling) would not bias the results by introducing variations in $\mathrm{rCBF}$ and tracer transport across the blood-brain barrier.

\section{Statistical Analyses}

Age, gender, and age-by-gender interactions with regional binding to mu-opioid receptors were explored by using independent analyses of covariance (ANCOVAs) for each of the brain regions considered, with sex as the independent variable, age as the covariate, and the regional receptor measure as the dependent variable. Statistically significant differences between subject groups of the same age were tested with two-tailed, unpaired t tests. Associations between regional binding potential and age were also tested with Pearson correlations. The minimum level of significance for all tests was $p<0.05$. No correction for multiple comparisons was applied. The data are expressed as mean values plus or minus one standard deviation.

\section{RESULTS}

The scan data obtained from the retrospective analysis and the prospectively recruited group were significantly different. Greater differences between regions and higher levels of receptor binding were shown by the data obtained with the newer-generation scanner (see Method, Prospective Analysis), reflecting improved spatial resolution and $\mathrm{z}$ axis sampling (data not shown: all regions showed differences between the data acquired with the two scanner types; unpaired, two-tailed t tests, $\mathrm{df}=64, \mathrm{p}<0.05)$. Therefore, these groups were not combined for any of the analyses presented.

There were no significant differences in age between the male and female subjects in either group (unpaired, two-tailed t tests; retrospective data: $\mathrm{t}=0.1, \mathrm{df}=34$, $\mathrm{p}>0.05$; prospective data: $\mathrm{t}=0.4, \mathrm{df}=28, \mathrm{p}>0.05)$. For the regions sampled in both hemispheres (neocortical regions, basal ganglia, and amygdala), no significant right-left asymmetries were observed in the men or women (paired, two-tailed t tests; retrospective group: $\mathrm{df}=34, \mathrm{p}>0.05$ for all regions examined; prospective group: $\mathrm{df}=28, \mathrm{p}>0.05$ for all regions); therefore, the right and left regions were averaged for subsequent analyses.

In addition, no age or sex effects were observed in activity in the occipital cortex, a reference region used for the estimation of nonspecific and free tracer activity (see Method) (one-way ANCOVA; retrospective group: $\mathrm{df}=1,33, \mathrm{p}>0.05$; prospective group: $\mathrm{df}=$ $1,27, \mathrm{p}>0.05)$. Activity in this region is a constant within each subject and reflects factors such as amount of radiotracer administered, metabolism and clearance of the parent compound, and tracer transport across the blood-brain barrier (see reference 21 and Method section).

\section{Retrospective Analysis}

Separate ANCOVAs for each region were calculated, with sex as a grouping factor, region as a dependent variable, and age as a covariate. The ANCOVAs did not show significant age-by-gender interactions for any brain region. Accordingly, the interaction term was eliminated from the model for subsequent analyses. Age effects were detected in the prefrontal $(\mathrm{F}=$ 11.4, $\mathrm{df}=1,33, \mathrm{p}<0.001)$, temporal $(\mathrm{F}=6.7, \mathrm{df}=1,33$, $\mathrm{p}<0.01)$, and parietal $(\mathrm{F}=7.7, \mathrm{df}=1,33, \mathrm{p}<0.01)$ cortices, amygdala $(\mathrm{F}=7.3, \mathrm{df}=1,33, \mathrm{p}<0.01)$, thalamus $(\mathrm{F}=$ 6.4, $\mathrm{df}=1,33, \mathrm{p}<0.01)$, and pons $(\mathrm{F}=10.8, \mathrm{df}=1,33, \mathrm{p}<$ $0.01)$. No significant age effects were observed in the anterior cingulate cortex, caudate, or putamen. Gender effects, with higher mu-receptor availability in the women than in the men, were detected in the temporal cortex $(\mathrm{F}=5.8, \mathrm{df}=1,33, \mathrm{p}=0.02)$, amygdala $(\mathrm{F}=9.6$, $\mathrm{df}=1,33, \mathrm{p}<0.01)$, and pons $(\mathrm{F}=6.8, \mathrm{df}=1,33, \mathrm{p}<0.01)$ and, to a lesser extent, in the parietal cortex $(\mathrm{F}=4.2$, $\mathrm{df}=1,33, \mathrm{p}<0.05)$ and caudate nucleus $(\mathrm{F}=4.2, \mathrm{df}=1$, $33, \mathrm{p}<0.05)$. No significant gender differences were observed in the prefrontal or anterior cingulate cortex, putamen, or thalamus.

The direction of age-related changes in mu-opioid receptor binding potential were further analyzed by means of Pearson's correlations. Negative associations between mu-opioid receptor binding and age were found in some subcortical structures: amygdala $(\mathrm{r}=-0.38, \mathrm{df}=34, \mathrm{p}=$ $0.02)$, thalamus $(\mathrm{r}=-0.41, \mathrm{df}=34, \mathrm{p}<0.01)$, and pons $(\mathrm{r}=-0.46, \mathrm{df}=34, \mathrm{p}<0.005)$. Conversely, mu-receptor binding increased with age in neocortical areas: prefrontal cortex $(\mathrm{r}=0.49, \mathrm{df}=34, \mathrm{p}=0.002)$, temporal cortex $(\mathrm{r}=0.39, \mathrm{df}=34, \mathrm{p}=0.02)$, and parietal cortex $(\mathrm{r}=$ $0.42, \mathrm{df}=34, \mathrm{p}<0.01)$. These corresponded to mean increases in mu-opioid receptor binding of $17 \%-34 \%$, from the third decade of age $(\mathrm{N}=15)$ to the seventh and eighth decades $(\mathrm{N}=7)$, in neocortical areas. In the amygdala, thalamus, and pons, binding decreased by $19 \%$, 34\%, and 39\%, respectively.

\section{Prospective Study}

ANCOVA detected significant age and sex effects, as well as sex-by-age interactions, in various brain regions. Age effects were observed in the prefrontal $(\mathrm{F}=$ $38.7, \mathrm{df}=1,27, \mathrm{p}<0.0001)$, anterior cingulate $(\mathrm{F}=19.9$, $\mathrm{df}=1,27, \mathrm{p}<0.0001)$, temporal $(\mathrm{F}=34.9, \mathrm{df}=1,27, \mathrm{p}<$ $0.0001)$, and parietal $(\mathrm{F}=53.3, \mathrm{df}=1,27, \mathrm{p}<0.0001)$ cortices and in the putamen $(\mathrm{F}=14.4, \mathrm{df}=1,27, \mathrm{p}<$ 0.001). The coefficients for Pearson correlations between age and regional binding potential reached $\mathrm{r}$ values of $0.72,0.70,0.70,0.78$, and 0.58 for the preceding respective regions $(\mathrm{df}=28, \mathrm{p}<0.001)$. The subjects in the third decade of age $(\mathrm{N}=9)$ had higher levels than did the subjects older than $60(\mathrm{~N}=10)$; the percentage differences for the preceding regions were $79 \%, 50 \%$, $62 \%, 89 \%$, and $36 \%$, respectively.

Gender effects were detected in the prefrontal, anterior cingulate, temporal, and parietal cortices, the cau- 
date nucleus, and the cerebellum; higher levels of muopioid receptor availability were present in the women (table 1 and figure 1). No sex differences were noted in the putamen.

Statistically significant age-by-gender interactions were detected in the amygdala and thalamus (figure 1 and table 1 footnote). The nature of these interactions was further explored by analyzing age and gender effects separately. In the men $(\mathrm{N}=12)$, no significant correlations with age were observed in these regions (Pearson correlations, $\mathrm{df}=10, \mathrm{p}>0.05)$. In the women $(\mathrm{N}=18)$, regional binding was negatively correlated with age (amygdala: $\mathrm{r}=-0.63, \mathrm{df}=16, \mathrm{p}<0.01$; thalamus: $\mathrm{r}=-0.42, \mathrm{df}=16, \mathrm{p}=0.07)$. Reproductive-age women $(\mathrm{N}=11$, mean age $=26$ years, $\mathrm{SD}=5$, range $=19$ 32) were also compared with men in the same age range $(\mathrm{N}=7$, mean age $=30$ years, $\mathrm{SD}=7$, range $=21-39)$, and those women showed higher levels of binding (unpaired, two-tailed t tests). In the amygdala, the mean difference was $29 \%(\mathrm{t}=3.7, \mathrm{df}=16, \mathrm{p}<0.005)$, and in the thalamus the mean difference was $23 \%(t=3.4, d f=$ $16, \mathrm{p}<0.005)$. When the postmenopausal women $(\mathrm{N}=$ 5 , mean age $=73$ years, $\mathrm{SD}=6$, range $=64-79)$ were compared to men in the same age range $(\mathrm{N}=4$, mean age $=$ 71 years, $S D=4$, range $=66-74)$, their binding was found to be below the men's levels, with mean differences of $-24 \%$ in the amygdala and $-12 \%$ in the thalamus. Two-tailed, unpaired $t$ tests did not show statistically significant differences for this age group, likely because of the small number of subjects included.

Even in the regions in which sex effects but no sexby-age interactions were observed, there was a tendency toward greater female-male differences in muopioid receptor binding during the reproductive years than after the menopause. Reproductive-age women had an average of $26 \%$ more binding than men in the prefrontal cortex, $24 \%$ in the anterior cingulate, $25 \%$ in the temporal cortex, $8 \%$ in the parietal cortex, $20 \%$ in the caudate nuclei, and $62 \%$ in the cerebellum. In the postmenopausal women and same-age men, these differences were somewhat less pronounced: $14 \%$ higher binding among the women in the prefrontal cortex, $7 \%$ in the anterior cingulate, and $13 \%$ in the temporal cortex. The women's receptor availability was $13 \%$ below male levels in the caudate nucleus. Binding was $19 \%$ and $59 \%$ higher in the parietal cortex and cerebellum, respectively.

\section{DISCUSSION}

The endogenous opioid system, the effects of which are mediated by three primary receptor subtypes (mu, delta, and kappa), has been implicated in a number of normal functions and may be altered in various pathological states. It appears to modulate responses to stress, learning, and memory acquisition, it is involved in the effects of substances of abuse, it regulates pain mechanisms, and it has been implicated in the pathophysiology of various illnesses, such as seizure disor-
TABLE 1. Sex Differences in Regional Mu-Opioid Receptor Binding in the Brains of Healthy Volunteers ${ }^{a}$

\begin{tabular}{|c|c|c|c|c|c|c|}
\hline \multirow[b]{4}{*}{ Region } & \multicolumn{4}{|c|}{$\begin{array}{c}\text { [11C]Carfentanil Specific } \\
\text { Binding ([region of inter- } \\
\text { est }- \text { nonspecific binding] } \\
\div \text { nonspecific binding) } \\
\end{array}$} & \multirow{2}{*}{\multicolumn{2}{|c|}{$\begin{array}{c}\text { One-Way } \\
\text { ANCOVA for Sex } \\
\text { Effect }^{\mathrm{C}}\end{array}$}} \\
\hline & \multirow{2}{*}{\multicolumn{2}{|c|}{$\begin{array}{c}\text { Men } \\
(\mathrm{N}=12)\end{array}$}} & \multirow{2}{*}{\multicolumn{2}{|c|}{$\begin{array}{l}\text { Women } \\
(\mathrm{N}=18)\end{array}$}} & & \\
\hline & & & & & $\mathrm{F}($ & \\
\hline & Mean & $\mathrm{SD}$ & Mean & $\mathrm{SD}$ & $1,27)$ & $\mathrm{p}$ \\
\hline Anterior cingulate & 2.1 & 0.8 & 2.4 & 0.5 & 5.1 & $0.03^{d}$ \\
\hline Prefrontal cortex & 1.7 & 0.7 & 2.0 & 0.6 & 6.4 & $0.02^{\mathrm{d}}$ \\
\hline Parietal cortex & 1.4 & 0.4 & 1.6 & 0.5 & 5.0 & $0.03^{d}$ \\
\hline Temporal cortex & 1.8 & 0.7 & 2.1 & 0.5 & 7.8 & $0.01^{d}$ \\
\hline Amygdala ${ }^{e}$ & 3.0 & 0.5 & 3.5 & 0.6 & 12.2 & $0.002^{\mathrm{d}}$ \\
\hline Thalamus $^{\mathrm{e}}$ & 3.8 & 0.8 & 4.4 & 0.6 & 10.3 & $0.004^{d}$ \\
\hline Caudate & 4.0 & 0.9 & 4.7 & 0.7 & 4.8 & $0.04^{d}$ \\
\hline Putamen & 3.4 & 0.8 & 3.5 & 0.7 & 0.5 & 0.5 \\
\hline Pons & 1.6 & 0.6 & 2.0 & 0.5 & 6.4 & $0.02^{d}$ \\
\hline Cerebellum & 0.9 & 0.4 & 1.6 & 0.4 & 20.5 & $0.0001^{d}$ \\
\hline
\end{tabular}

a Subjects were between the ages of 19 and 79 years and were scanned with a GE $4096^{+}$PET system. All reproductive-age women were studied during the follicular phase of the menstrual cycle (between days 4 and 10 after the onset of menses), and neither the pre- nor postmenopausal women had taken hormonal treatments for at least 6 months before the study.

${ }^{b}$ Nonspecific binding was obtained in the occipital cortex, an area devoid of mu-opioid receptor binding. This ratio is proportional to the $B_{\text {max }} / K_{d}$ of mu-opioid receptors.

${ }^{c}$ With age as covariate. Minimum level of statistical significance, $\mathrm{p}<0.05$.

d Significant difference between groups.

${ }^{\mathrm{e}}$ Age-by-sex interactions detected in the amygdala ( $\mathrm{F}=7.0, \mathrm{df}=1$, $26, p=0.01)$ and thalamus $(F=5.6, d f=1,26, p=0.03)$.

ders, depressive illness, eating disorders, and Alzheimer's disease.

The data presented here, replicated in two different study groups, demonstrate both age- and sex-associated differences in mu-opioid receptor binding measures in the brains of living healthy humans. The influences of age and sex on this neuroreceptor site were observed in some, but not other, regions.

We observed increases in mu-opioid receptor availability with advancing age in neocortical regions and the putamen, findings that are consistent with data obtained in studies of experimental animals and two human postmortem studies $(16,17)$. While our method of analysis (binding potential, $\mathrm{B}_{\max } / \mathrm{K}_{\mathrm{d}}[22]$ ) does not differentiate changes in receptor binding $\left(B_{\max }\right)$ from changes in receptor affinity $\left(\mathrm{K}_{\mathrm{d}}\right)$, the study of Gross-Isseroff et al. (16) showed that regional age-related changes in mu-opioid receptor binding observed in postmortem subjects (up to $30 \%-60 \%$ of whom were in their third to sixth decades) were related to alterations in $\mathrm{B}_{\max }$ and not $\mathrm{K}_{\mathrm{d}}$. The percentage increase described in their work is also comparable to that observed in the present study for subjects in the prospectively recruited group, who were studied with the higher-resolution scanning system.

Women showed higher mu-opioid receptor binding values than men in several brain regions, both cortical and subcortical. With the ANCOVA model, significant sex effects were detected in neocortical areas (prefron- 
FIGURE 1. Age-Related Changes in Mu-Opioid Receptor Binding in Four Representative Brain Regions of Healthy Men and Women ${ }^{a}$
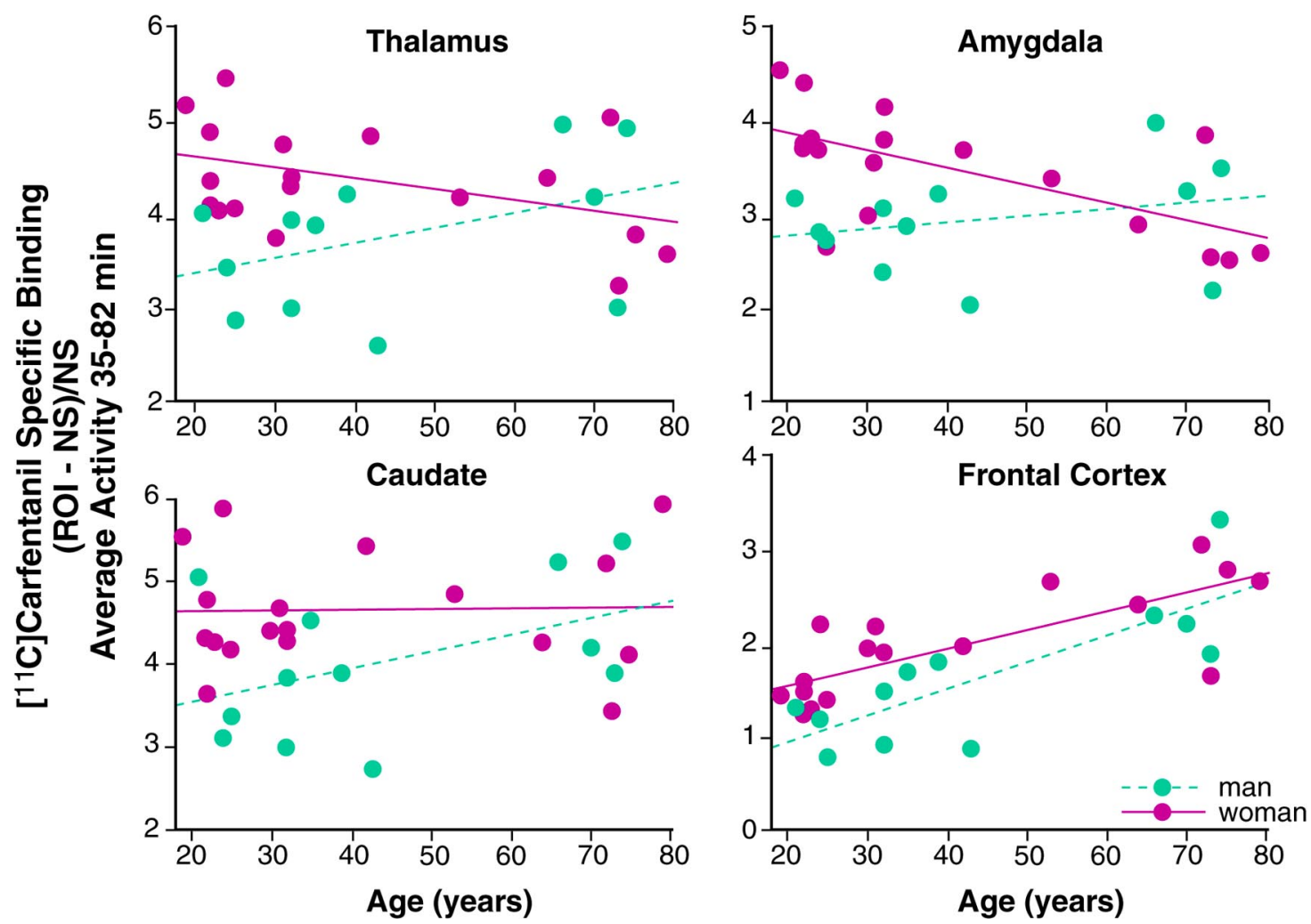

a The subjects were scanned with a GE $4096^{+}$PET system. ROI=region of interest; NS=nonspecific binding, obtained in the occipital cortex, an area devoid of mu-opioid receptor binding. The ratio (ROI - NS) / NS is proportional to the $B_{\max } / K_{d}$ of mu-opioid receptors. All reproductive-age women were studied during the follicular phase of the menstrual cycle (between days 4 and 10 after the onset of menses), and neither the pre- nor postmenopausal women had taken hormonal treatments for at least 6 months before the study. In the thalamus and amygdala, age-by-sex interactions were observed. In other regions, including the anterior cingulate and prefrontal, temporal, and parietal cortices, sex differences, but no sex-by-age interactions, reached significant levels. In the putamen, neither sex nor age-by-sex interactions were noted, although age effects reached statistically significant values in the ANCOVA model.

tal, parietal, temporal) and in the caudate nuclei, amygdala, thalamus, and cerebellum (but not in the putamen), if no correction for multiple comparisons was applied. If the threshold of significance was reduced to account for multiple tests, the regions that remained significant would be limited to the amygdala, thalamus, and cerebellum. It is interesting that the ageassociated changes differed between the sexes in the amygdala and thalamus. While women had higher opioid binding potential than men during the reproductive years, binding decreased below that in men after the menopause. This was reflected in the ANCOVA model as a sex-by-age interaction. A number of other regions also showed smaller male-female differentials after the menopause, although not to the extent observed in the amygdala or thalamus. While the sex differences in mu-opioid binding during the female reproductive years may reflect early, gender-specific ontogenetic factors, the changes observed in the postmenopausal women suggest that the adult hormonal milieu is also capable of modulating this neurochemical system at least in some brain regions.
Some differences between the data acquired with the two scanning systems and patient groups were apparent. More regions were found to show age and gender effects with the newer scanning system, a finding that is likely accounted for by improved spatial resolution and sensitivity. In addition, a larger number of women were studied in the prospectively recruited group, which may have increased our ability to find differences between genders and age-by-gender interactions.

We considered the possibility that technical issues may have influenced the data. Factors that sometimes confound the interpretation of PET receptor measures include changes in blood flow (and therefore bloodbrain transport of the radiotracer). For some radiotracers, regional changes in CBF may influence the receptor measure if uptake is "flow dependent" (24). However, computer simulations in which modifications in radiotracer transport $\left(\mathrm{K}_{1}\right)$ were introduced showed that the distribution of $\left[{ }^{11} \mathrm{C}\right]$ carfentanil is not subject to significant flow effects. Also, rCBF tends to decrease with advancing age, while mu-opioid receptors increased in most brain regions with advancing age, in agreement with postmortem data $(16,17)$. 
A second element that causes erroneous measurements is the presence of partial volume effects due to limited resolution and differential degrees of regional atrophy (25). Smaller brain regional volumes imply less recovery of tracer activity. While correction for atrophic changes was not applied to these data, women and men have not been shown to have such differences in cortical gray volumes $(10,15)$, and so this issue does not explain either the sex differences observed during the reproductive years or the decline in binding observed in the postmenopausal women.

The data presented have important theoretical and practical implications. First, they experimentally support the recent policy of including both sexes in human research. They also imply that functions in which the opioid system plays a role, such as antinociceptive or reward mechanisms, may be differentially modulated by gender and age.

In one study (19) a more profound effect of kappaopioid agonists was observed in women than in men. While systematic data addressing sex differences in mu-opioid agonist antinociception in humans are not available, our results suggest that these may also be present. In this regard, the amygdala and the thalamus have been implicated in antinociceptive function (26). The higher mu-opioid receptor binding would predict that sensitivity to mu-opioid analgesics would be greater in reproductive-age women than in men, with the reverse being the case in postmenopausal women. However, in the present study there were too few older subjects to compare them to the younger subjects, so this hypothesis should be reexamined in larger cohorts. Also, the finding of sex-by-age interactions in the amygdala and the thalamus would not survive after correction for multiple comparisons. Further studies will require specific attention to reproductive status to confirm our findings and explore their physiological implications.

Other behavioral and cognitive implications of our findings are still to be explored. The opioid system is thought to be involved in a variety of human functions, including emotional and reward regulation, learning, and memory acquisition. For example, mu-opioid receptors are modulated as a response to stressors (27, 28). High levels have been found in the frontal cortex of suicide victims $(16,17)$ and may be present in patients diagnosed with major depression (29). High doses of naloxone, a nonselective opioid antagonist, appear to interfere with performance in verbal learning tasks (30). It is interesting that women usually outperform men in verbal functions but have worse performance after menopause or surgical oophorectomy (31, 32). Hypoestrogenemia may also worsen the course of Alzheimer's disease (33). In this illness, low mu-opioid receptor binding in the amygdala has been described in human postmortem tissue (34). The influence of gonadal steroids on amygdala mu-opioid binding and its implications remain to be examined.

Much work remains to be done in the study of gender and age effects on neurochemical systems in hu- man subjects. This report points to one neurotransmitter system, the endogenous opioid, for which both factors have significant brain regional influences. Further studies should be targeted to the examination of the behavioral and cognitive implications of these influences in normal processes (e.g., cognition, emotional processing) and in disease states (e.g., substance abuse, painful conditions) in which the opioid system may play a key role.

\section{REFERENCES}

1. Albert MS, Kaplan E: Organic implication of neuropsychological deficits in the elderly, in New Directions in Memory and Aging: Proceedings of the George A. Talland Memorial Conference. Edited by Poon LW, Fozard J, Cermak L. Hillsdale, NJ, Lawrence Erlbaum Associates, 1980, pp 403-432

2. Brody $\mathrm{H}$ : Organization of the cerebral cortex, II: a study of aging in human cerebral cortex. J Comp Neurol 1955; 102:511556

3. Finch $\mathrm{CE}$ : Biochemistry of aging in the mammalian brain, in Basic Neurochemistry: Molecular, Cellular, and Medical Aspects, 5th ed. Edited by Siegel CJ, Agranoff BW, Albers RW. New York, Raven Press, 1994, pp 627-644

4. Murphy DGM, DeCarli C, Schapiro MB, Rapoport SI, Horwitz B: Age-related differences in volumes of subcortical nuclei, brain matter, and cerebrospinal fluid in healthy men as measured with magnetic resonance imaging. Arch Neurol 1992; 49:839-845

5. Coffey CE, Wilkinson WE, Parashos IA, Soady SA, Sullivan RJ, Patterson LJ, Figiel GS, Webb MC, Spritzer CE, Djang WT: Quantitative cerebral anatomy of the aging human brain: a cross-sectional study using magnetic resonance imaging. Neurology 1992; 42:527-536

6. Pantano P, Baron JC, Lebrun-Grandie P, Duquesnoy N, Bousser MG, Comar D: Regional cerebral blood flow and oxygen consumption in human aging. Stroke 1984; 15:635-641

7. Kuhl DE, Metter EJ, Riege WH, Phelps ME: Effects of human aging on patterns of local cerebral glucose utilization determined by the $\left[{ }^{18} \mathrm{~F}\right]$ fluorodeoxyglucose method. J Cereb Blood Flow Metab 1982; 2:163-171

8. Salmon E, Maquet P, Sadzot B, Degueldre C, Lemaire C, Franck G: Decrease of frontal metabolism demonstrated by positron emission tomography in a population of healthy elderly volunteers. Acta Neurol Belg 1991; 91:288-295

9. Takeda S, Matsuzawa T: Age-related brain atrophy: a study with computed tomography. J Gerontol 1985; 40:159-163

10. Gur RC, Mozley PD, Resnick SM, Gottlieb GL, Kohn M, Zimmerman R, Herman G, Atlas S, Grossman R, Berretta D, Erwin R, Gur RE: Gender differences in age effect on brain atrophy measured by magnetic resonance imaging. Proc Natl Acad Sci USA 1991; 88:2845-2849

11. Gur RC, Gur RE, Obrist WD, Hungerbuhler JP, Younkin D, Rosen AD, Skolnick BE, Reivich M: Sex and handedness differences in cerebral blood flow during rest and cognitive activity. Science 1982; 217:659-661

12. Baxter LR Jr, Mazziotta JC, Phelps ME, Selin CE, Guze BH, Fairbanks L: Cerebral metabolic rates for glucose in normal human females versus normal males. Psychiatry Res 1987; 21:237-245

13. Volkow ND, Wang G-J, Fowler JS, Hitzemann R, Pappas N, Pascani K, Wong C: Gender differences in cerebellar metabolism: test-retest reproducibility. Am J Psychiatry 1997; 154: 119-121

14. Gur RC, Mozley LH, Mozley PD, Karp JS, Alavi A, Arnold SE, Gur RE: Sex differences in regional cerebral glucose metabolism during a resting state. Science 1995; 267:528-531

15. Murphy DGM, DeCarli C, Mclntosh AR, Daly E, Mentis MJ, Pietrini P, Sczepanik J, Schapiro MB, Grady CL, Horwitz B, Rapoport SI: Sex differences in human brain morphometry and metabolism: an in vivo quantitative magnetic resonance imag- 
ing and positron emission tomography study on the effect of aging. Arch Gen Psychiatry 1996; 53:585-594

16. Gross-Isseroff R, Dillon KA, Israely M, Biegon A: Regionally selective increases in $\mu$-opioid receptor density in brains of suicide victims. Brain Res 1990; 530:312-316

17. Gabilondo AM, Meana JJ, Garcia-Sevilla JA: Increased density of mu-opioid receptors in the postmortem brain of suicide victims. Brain Res 1995; 682:245-250

18. Hammer RP: The sexually dimorphic region of the preoptic area in rats contains denser opiate receptor binding sites in females. Brain Res 1984; 308:172-176

19. Gear RW, Miaskowski C, Gordon MC, Paul SM, Heller PH, Levine JD: Kappa opioids produce significantly greater analgesia in women than in men. Nat Med 1996; 2:1248-1250

20. Meltzer CC, Bryan N, Holcomb HH, Kimball AW, Mayberg HS, Sadzot B, Leal JP, Wagner HNJ, Frost JJ: Anatomical localization for PET using MR imaging. J Comput Assist Tomogr 1990; 14:418-426

21. Frost JJ, Douglass KH, Mayberg HS, Dannals RF, Links JM, Wilson AA, Ravert HT, Crozier WC, Wagner HN Jr: Multicompartmental analysis of $\left[{ }^{11} \mathrm{C}\right]$ carfentanil binding to opiate receptors in humans measured by positron emission tomography. J Cereb Blood Flow Metab 1989; 9:398-409

22. Mintun MA, Raichle ME, Kilbourn MR, Wooten GF, Welch MJ: A quantitative model for the in vivo assessment of drug binding sites with positron emission tomography. Ann Neurol 1984; 15:217-227

23. Price JC, Mayberg HS, Dannals RF, Wilson AA, Ravert HT, Sadzot B, Rattner Z, Kimball A, Feldman MA, Frost JJ: Measurement of benzodiazepine receptor number and affinity in humans using tracer kinetic modeling, positron emission tomography, and $\left[{ }^{11} \mathrm{C}\right]$ flumazenil. J Cereb Blood Flow Metab 1993; 13:656-667

24. Koeppe RA, Frey KA, Mulholland MR, Kilbourn MR, Buck A, Lee KS, Kuhl DE: $\left[{ }^{11} \mathrm{C}\right]$ Tropanyl benzylate-binding to muscar- inic cholinergic receptors: methodology and kinetic modeling alternatives. J Cereb Blood Flow Metab 1994; 14:85-99

25. Links JM, Zubieta JK, Meltzer CC, Stumpf MJ, Frost JJ: Influence of spatially heterogeneous background activity on "hot object" quantitation in brain emission computed tomography. $\mathrm{J}$ Comput Assist Tomogr 1996; 20:680-687

26. Manning $\mathrm{BH}$, Mayer DJ: The central nucleus of the amygdala contributes to the production of morphine antinociception in the rat tail-flick test. J Neurosci 1995; 15:8199-8213

27. Akil H, Madden J, Patrick RL, Barchas JD: Stress-induced increase in endogenous opiate peptides: concurrent analgesia and its partial reversal by naloxone, in Opiate and Endogenous Opiate Peptides. Edited by Kosterlitz HW. Amsterdam, Elsevier, 1976, pp 63-70

28. Stein EA, Hiller JM, Simon EJ: Effects of stress on opioid receptor binding in the rat central nervous system. Neuroscience 1992; 51:683-690

29. Zubieta JK, Treisman GL, Fishman M, Dannals RF, Ravert HT, Frost JJ: Increased mu opioid receptor binding in unmedicated major depression: a PET study with $\left[{ }^{11} \mathrm{C}\right]$ carfentanil (abstract). J Nucl Med 1995; 36:21P

30. Cohen RM, Cohen MR, Weingartner H, Pickar D, Murphy DL: High-dose naloxone affects task performance in normal subjects. Psychiatry Res 1983; 8:127-136

31. Phillips SM, Sherwin BB: Effects of estrogen on memory function in surgically menopausal women. Psychoneuroendocrinology 1992; 17:485-495

32. Kampen DL, Sherwin BB: Estrogen use and verbal memory in healthy postmenopausal women. Obstet Gynecol 1994; 83: 979-983

33. Paganini-Hill A, Henderson VW: Estrogen deficiency and risk of Alzheimer's disease in women. Am J Epidemiol 1994; 140: 256-261

34. Hiller JM, Itzhak Y, Simon EJ: Selective changes in $\mu, \delta$ and $\kappa$ opioid binding in certain regions of the brain in Alzheimer's disease patients. Brain Res 1987; 406:17-23 